\title{
E-Media Development as an Effort to Improve Primary School Student Learning Results in Semarang
}

\author{
Farid Ahmadi ${ }^{\mathrm{a}}$, Fakhruddin ${ }^{\mathrm{b}}$, Trimurtini ${ }^{\mathrm{c}}$ \\ Primary Teacher Education Department \\ Faculty of Education \\ State University of Semarang \\ Corresponding e-mail: ${ }^{a}$ farid@mail.unnes.ac.id, ${ }^{b}$ fakhruddin@mail.unnes.ac.id, \\ ctrimurtinipgsd@mail.unnes.ac.id
}

\begin{abstract}
Preliminary study conducted in some elementary schools located in Semarang found that the information and communication technology-based learning media was not optimally implemented. The type of this research is Research and Development with Waterfall SDLC research model consisting of: analysis, design, implementation, testing, and maintenance. The aim of this research is to know the development, to test the feasibility, and to test the effectiveness of ICT-based interactive learning media in fourth grade of Tunas Harum Bangsa Elementary School in Semarang, Third and Fifth Grade of State Elementary School of Karangayu 02 Semarang. The research design was one-group pre-test post-test. The feasibility test results using material and media validators considered in good criteria (feasible). The pre-test and post-test learning outcomes calculated using $\mathrm{N}$-gain showed enhancement and considered as moderate criteria (quite feasible). Based on the hypothesis test with SPSS t-test (Paired Samples Test), obtained Sig (2-tailed) $=0,000<0,05$ then $\mathrm{Ha}$ accepted, meaning the use of ICT-based interactive learning media can improve primary school student learning results in Semarang.
\end{abstract}

Keywords: Learning Results; Learning Media

\section{INTRODUCTION}

Based on Law No. 20 Year 2003 Chapter 1 Article 1 on National Education System mentions that education is a conscious and planned effort to create an atmosphere of learning and learning process so that the learners actively develop their potential to have religious spiritual strength, self-control, personality, intelligence, noble character, as well as the necessary skills needed by $\mathrm{him} /$ herself, society, nation and state. Therefore, Social Sciences subject is included in the Primary School curriculum which aims to encourage learners in solving social problems that occur in the society. According to the Content Standards in Regulation of the Minister of National Education (Peraturan Menteri Pendidikan Nasional) No.22 of 2006, the scope of Social Sciences subject includes these following aspects: (1) Human, Place, and Environment. (2) Time, Sustainability, and Change. (3) Social and Cultural System. (4) Economic Behavior and Welfare.

The essence of learning process is the communication process and basically a unit of system and becomes inseparable parts in the learning process (Daryanto, 2016: 7). Azhar
Arsyad (2013: 2) also reveals that the media is needed for the purpose of achieving learning objectives in school specifically and or achieving the goal of education in general.

Based on the results of preliminary research conducted at Tunas Harum Bangsa Elementary School Semarang and Karangayu State Elementary 02 Semarang obtained the value of Social Sciences subject in grade IV of Tunas Harum Bangsa Elementary School in Semarang and in class V-B of Karangayu Elementary School 02 of Semarang. While in class III-B Karangayu Elementary School of Semarang, the students had the lowest score in Citizenship education subject (Indonesian, Pendidikan Kewarganegaraan or known its acronym as $\mathrm{Pkn}$ ). 
Table 1. Completeness of Minimum Standard

\begin{tabular}{|c|c|c|c|c|}
\hline \multirow[b]{2}{*}{ No } & \multirow[b]{2}{*}{ Subject } & \multicolumn{3}{|c|}{ Completeness } \\
\hline & & $\begin{array}{l}\text { Grade } \\
\text { IV ES } \\
\text { of THB }\end{array}$ & $\begin{array}{l}\text { Class III-B } \\
\text { ES of } \\
\text { Karangayu } \\
02\end{array}$ & $\begin{array}{c}\text { Class V-B } \\
\text { ES of } \\
\text { Karangayu } \\
02\end{array}$ \\
\hline 1 & $\begin{array}{l}\text { Indonesian } \\
\text { Language } \\
\text { (Bahasa } \\
\text { Indonesia) }\end{array}$ & $88 \%$ & $24,14 \%$ & $61,29 \%$ \\
\hline 2 & Mathematics & $100 \%$ & $58,62 \%$ & $67,74 \%$ \\
\hline 3 & $\begin{array}{l}\text { Natural } \\
\text { Sciences }\end{array}$ & $80 \%$ & $44,83 \%$ & $70,96 \%$ \\
\hline 4 & Social Sciences & $68 \%$ & $58,62 \%$ & $58,06 \%$ \\
\hline 5 & $\begin{array}{l}\text { Citizenship } \\
\text { education }\end{array}$ & $80 \%$ & $37,93 \%$ & $67,74 \%$ \\
\hline
\end{tabular}

In this study, the researcher chooses to develop information and communication technology-based interactive learning media. ICT-based interactive learning media is more specified into four learning media, these are macromedia flash and website on Tumblr for grade IV students of Tunas Harum Bangsa Elementary School of Semarang, android for class III-B students of Karangayu Elementary School 02 of Semarang, and interactive Power point (power point) for class V-B students of Karangayu Elementary School 02 of Semarang.

Learning media are classified by the purpose of usage and characteristics of media type. According to Gerald \& Ely in Daryanto (2016: 18) the media are grouped in accordance with their physical characteristics which consist of eight groups, such as actual objects, verbal presentations, graphic presentations, still images, moving pictures, sound recording, programmable images, and simulation. The classification of the media will make it easier for teachers to make the right media selection when planning the learning activities.

Daryanto (2016: 13) states that students will be easier to learn concrete things rather than the abstract things. Jerome Bruner argues the learning process should use the sequence of learning with images (iconic) first and then to learn with symbols (symbolic). Android technology is expected to be applied to various things similarly to the existing computer system, the developing media must contain concrete things (can be video and image) and in the form of abstract icons (symbol). Azhar Arsyad (2013: 25-27) also reveals by using learning theory in learning process, the lessons learned can be more interactive.
Madcoms in Journal of Agri Science (2014: 178) states Macromedia Flash Professional 8 is one of the animation design software makers. This software is very popular and has been recognized its sophistication and completeness regarding its facilities that are able to create animated designs, making the software is mostly and widely used by computer designers. The display presented will make the learners freely to choose, synthesize, and elaborate the knowledge they want to understand. Thus, Macromedia Flash Professional 8 can be used to develop multimedia-based learning media. The produced multimedia here is interactive multimedia.

This study was also supported by findings in the Proceedings of the Scientific Meeting Journal Vol.24 pp. 195-199 entitled "Web Based Learning Assessment System" which states that the test results of application program quality are feasible to be used for evaluation and completion of question items.

Another supporting research was a research conducted by Isma Ramadhani Lubis and Jaslin Ikhsan. From the research results, the post-test in experimental class obtained 80,31 with the improvement score of motivation of 0,31 , while control class was only 77,81 with motivation increase of 0,16 . From the data analysis using Manova, it obtained sig value. $<0,05$, indicating that there was improvement on learners' cognitive achievement especially they were who learned using android based media compared to those who had used conventional learning media.

The study written in the international journal, Turkish Science Education from Yüzüncü Yıl University, VanTurkey conducted by Naki Erdemir in 2011 Volume 8-3 entitled "The Effect of Powerpoint and Traditional Lectures on Students' Achievement in Physics" showed the use of Power point in physics course had improved the success of learners.

Based on the background of problems that have been described then the purposes of this study are: 1) Developing interactive learning media based on ICT in Primary Schools in Semarang; 2) Knowing the feasibility of ICT-based interactive learning media in Elementary School in Semarang and; 3) Knowing the effectiveness of ICT-based interactive learning media in Elementary Schools of Semarang. 


\section{RESEARCH METHOD}

The subjects of this study were students, teachers, experts, and researchers. Data collection techniques were test techniques including pre-test and post-test and non-test techniques such as interviews, questionnaires, and documentation. This type of research is research and development ( $R \& D)$, while the design of this study is one group pre-test posttest. The method is SDLC and Waterfall model which have 5 stages namely: Analysis, Design, Implementation, Testing, Maintenance referring to International Journal of research conducted by Youssef Bassil (2012, Volume 2, ISSN: 2049-3444) entitled "A Simulation Model for the Waterfall ", but the researcher limited the stages only to the testing phase. Here are the following stages of waterfall model in the fishbone diagram.

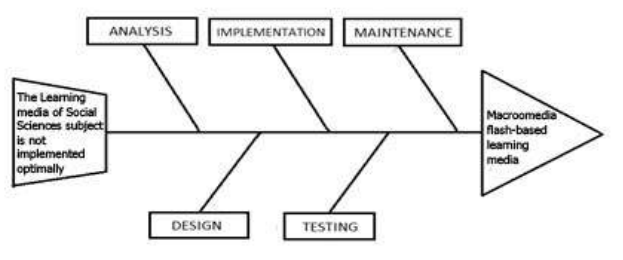

Figure 1. Diagram of Fishbone

The first stage of the research was analysis, at this stage the researcher interviewed about the needs of teachers and students to ICT-based interactive learning media. Secondly, at the design stage, the researcher designed flowcharts and prototypes. Third, the researcher implemented the design into an ICT-based interactive learning media. Fourth, researcher conducted feasibility tests valued by materials and media experts, then conducting small group trials and large group test, as well as teachers' and students' responses regarding ICT-based interactive learning media that had been used. Maintenance stage was not performed by the researcher, but being implemented by teachers and schools.

The research design used in this research was one-group pre-test post-test with the subjects of research were students, teachers, experts, and researchers. The variables of this research included dependent variable that was ICT-based interactive learning media and independent variables were the test results of grade IV students of THB Elementary School of Semarang, grade III students and $\mathrm{V}$ students of Karangayu Elementary School 02 of Semarang.

The data collection technique used by the researcher was a test technique consisting of pre-test and post-test, and non-test technique comprised of (1) documentation in the form of video, photos of research process and student value data, (2) questionnaire to find the media development requirement from teachers and students, to obtain the feasibility of the material and media experts, and to know the response of teachers and students to the use of ICT-based learning media, and (3) interviews. Initial data analysis techniques that were calculated using normality test, while the final data analysis was with $\mathrm{N}$-gain and hypothesis testing. Hypothesis test used was paired sample t-test.

\section{RESULTS AND DISCUSSION}

The results and discussion include ICTbased interactive media design, expert feasibility assessment, ICT-based interactive media effectiveness. The ICT-based learning media includes macromedia flash, website on Tumblr (WOT), android and interactive Power point.

\subsection{Development of ICT-Based Interactive Learning Media}

Macromedia flash-based multimedia interactive learning media is designed as a medium of Society Sciences learning of grade IV on the Maps materials and its properties.

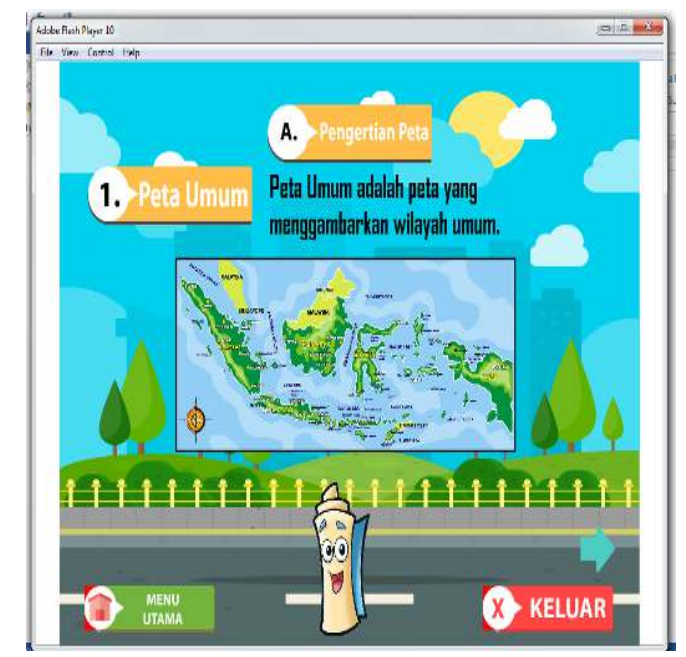

Figure 2. Android-based interactive learning media on material of Youth Pledge in Citizenship Education subject. 
Web-based interactive learning media on Tumblr (WOT), is designed as a medium of Society Sciences Learning in Grade IV on the material of Racial and Cultural Diversity.

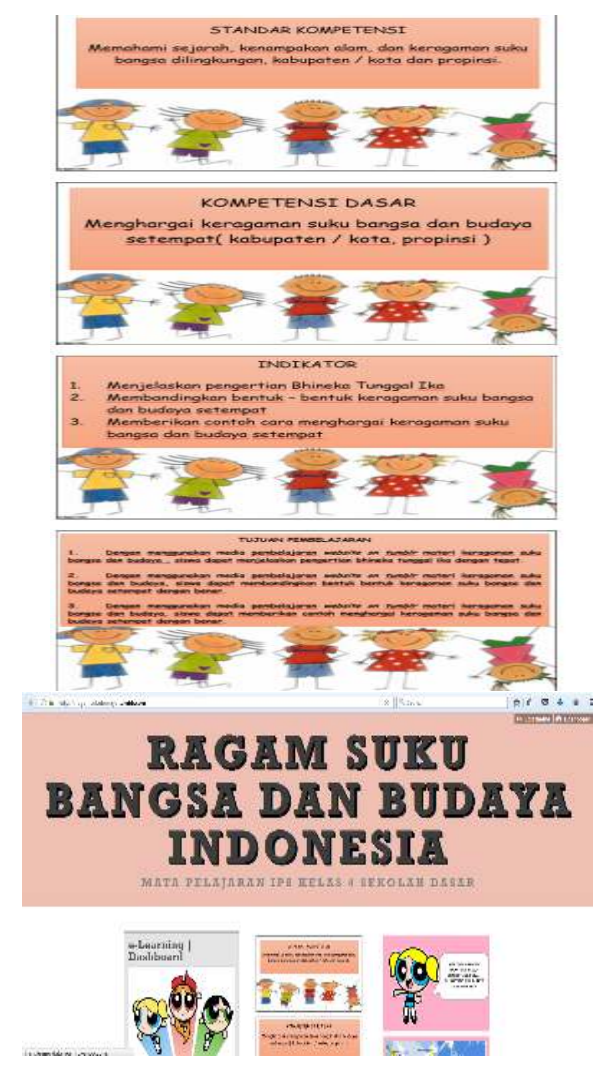

Figure 3. WOT-based Interactive learning media on the material of Indonesian Racial and Cultural Diversity included in Society Sciences subject

Android-based interactive learning media is designed as a medium of Society Sciences Subject learning of Grade III on the material of Youth Pledge.

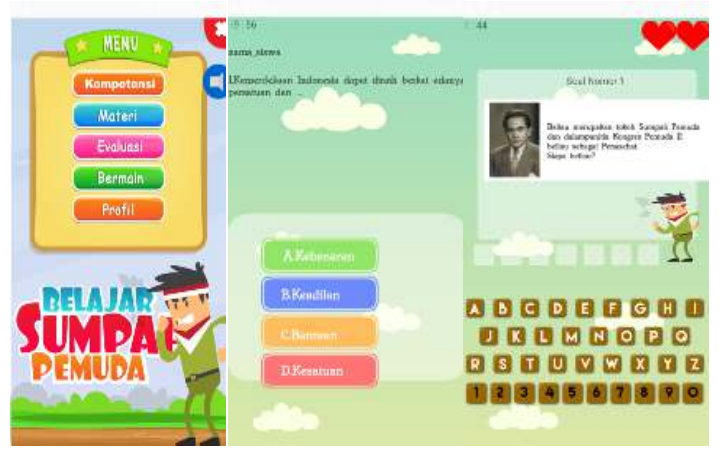

Figure 4. Android-based interactive learning media as medium of Youth Pledge material on Citizenship Education subject

Power point-based interactive learning media is designed as a learning media in
Society Sciences subject of Grade V on Racial and Cultural Diversity material.

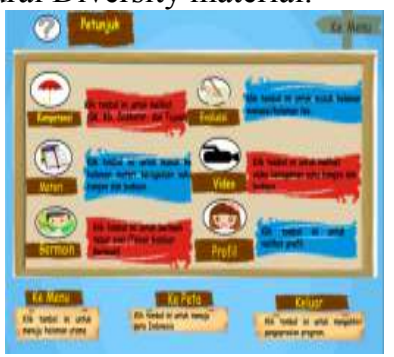

Figure 5. Power point-based interactive learning media as a medium of Indonesian Racial and Cultural Diversity of Society Sciences subject.

\subsection{Feasibility of ICT-based Interactive Learning Media}

The results of material expert test on macromedia flash-based multimedia interactive learning media got percentage value of $90 \%$ which was considered "very feasible", while the result of media test got the percentage value of $80 \%$ and considered "Feasible". The results of material expert test on web-based interactive learning media on Tumblr got the percentage value of $82 \%$ and considered very feasible. Furthermore, the media test results got the percentage value of $79 \%$ with the criteria of "Feasible". The results of material expert test on androidbased interactive learning media got the percentage value of $85 \%$ and categorized as very feasible, while the media test results got the percentage value of $79 \%$ and classified as "Feasible". The results of material expert test on power point-based interactive learning media got the percentage value of $89 \%$ and considered very feasible, while the media test results got the percentage value of $79 \%$ and grouped in "Feasible" category..

The feasibility criteria were determined based on interpretation of expert validation, according to Riduwan (2013: 15) in Proceedings of National Seminar on Accounting and Finance Education as follows.

Table 2. Expert Validation Interpretation Criteria

\begin{tabular}{cc}
\hline Percentage & Criteria \\
\hline $0 \%-20 \%$ & Very unfeasible \\
$21 \%-40 \%$ & Unfeasible \\
$41 \%-60 \%$ & Quite Feasible \\
$61 \%-80 \%$ & Feasible \\
$81 \%-100 \%$ & Very Feasible \\
\hline
\end{tabular}




\subsection{The Effectiveness of ICT- Based Interactive Learning Media}

In small group experiments on ICT-based interactive learning media, it had high and medium N-Gain including, macromedia flash of 0,39 , media website on tumblr of 0,83 , media android of 0,34 , power point media of 0,52 .

These criteria were based on the Improvement of Learning Result Criteria conducted by Hake (1998) in the Journal of Educational Research on Natural Sciences, 2016, Vol. 1, No. 1 as follows:

Table 3. Improvement of Learning Result Criteria

\begin{tabular}{cc}
\hline $\begin{array}{c}\text { Coefficient } \\
\text { Interval }\end{array}$ & Criteria \\
\hline $\mathrm{N}$-gain $<0,3$ & Low \\
$0,3 \leq \mathrm{N}$-gain $<0,7$ & Medium \\
$\mathrm{N}$-gain $\geq 0,7$ & High \\
\hline
\end{tabular}

Based on the results of large group tests, the average of pre-test result (before using ICT-based media) was macromedia flash of 72.35 , website on Tumblr of 57 , android media of 65,63 , and on power point media of 67.7, while the average of post-test (after using ICT-based media) was macromedia flash of 84.3, website on Tumblr of 84.5, android media of 85.21 , and on power point media of 79.8 .

In the large group test results obtained improvement on learning after using ICTbased interactive learning media with the achievement of understanding of 0,43 on the media of macromedia flash, 0,71 on media of website on Tumblr, 0,57 on the media of android, 0,59 on the media of power point including on the criteria of very high and medium. While on the paired sample test output with SPSS, it was gained Sig (2-tailed) of 0,000 . The score of Sig (2-tailed) was 0,000 $<0,05$, as well as on the macromedia flash ${ }^{t}$ count ${ }^{t}$ count $=4,948>>{ }^{t}$ table ${ }^{t}$ table $=$ 2,093, website media on Tumblr ${ }^{t}$ count ${ }^{t}$ count $=11,646>>{ }^{t}$ table ${ }^{t}$ table $=2,093$, android media ${ }^{t}$ count ${ }^{t}$ count $=8,027 \gg{ }^{t}$ table ${ }^{t}$ table $=1,711$, and on Power point media ${ }^{t}$ count ${ }^{t}$ count $=10,862>{ }^{t}{ }^{t}$ table ${ }^{t}$ table $=1,706$.

\section{CONCLUSION}

Based on the hypothesis testing that have been done, then according to the basis of decision making in paired sample test can be concluded that $\mathrm{Ho}$ is rejected and $\mathrm{Ha}$ is accepted, meaning ICT-based interactive learning media is effectively used and it can improve Primary School student learning results in Semarang.

\section{ACKNOWLEDGMENT}

The researcher would like to thank all the agencies that have supported this research so that it can be completed, Thanks to the entire team of experts who have validated the ICT learning media as the result of research.

\section{REFERENCES}

[1] Arikunto, Suharsimi. (2013). Prosedur Penelitian. Jakarta: Rineka Cipta.

[2] _ . (2012). Dasar-dasar Evaluasi Pendidikan. Jakarta: Bumi Aksara.

[3] Arsyad, Azhar. (2013). Media Pembelajaran. Jakarta: Raja Grafindo Persada.

[4] Bassil, Youssef. (2012). A Simulation Model for the Waterfall Software Development Life Cycle. Internatio-nal Journal of Engineering and Tech-nology. Volume 2 (5) : 743-749. ISSN 20493444

[5] Daryanto. (2016). Media Pembelajaran. Yogyakarta: Gava Media.

[6] Erdemir, Naki. (2011). "The Effect of Power Point and Traditional Lectures on Students' Achievement in Physics". Journal of Turkish Science Education. Volume 8 (3) : 176-189

[7] Fahmi, Syariful. (2014). Pengembangan Multimedia Macromedia Flash dengan Pendekatan Kontekstual dan Keefektifannya terhadap Sikap Siswa pada Matematika. Jurnal AgriSains Vol. 5 , no. 2

[8] Islamiyah, Nur Indah, Susanti. Pengembangan Modul Akuntansi Perusahaan Jasa Berbasis Pembelajaran Kontekstual pada Materi Jurnal Penyesuaian dan Jurnal Koreksi Kelas X Akuntansi SMK Negeri di Surabaya. Prosiding Seminar Nasional Pendidikan Akuntansi dan Keuangan.

[9] Permendiknas Nomor 22 Tahun 2006 tentang Standar Isi Untuk Satuan Pendidikan Dasar dan Menengah. 
[10] Setiawan, Beni, dkk. (2016). Penerapan Strategi Belajar Peta Konsep untuk meningkatkan Hasil Belajar Mahasiswa pada Mata Kuliah SAINS Sekolah Prodi S-1 Pendidikan IPA Unesa Surabaya. Jurnal Penelitian Pendidikan IPA Vol.1 No.1
[11] Sugiyono. (2015). Metode Penelitian \& Pengembangan Research and Development. Bandung: Alfabeta.

[12]_ . (2012). Statistika untuk Penelitian. Bandung: Alfabeta. 